\title{
Morphological features of the large intestine in experimental acute generalized peritonitis against the background of streptozotocin-induced diabetes
}

\begin{abstract}
The work is a fragment of the research project "Pathogenetic features of the allergic and inflammatory processes course and their pharmacocorrection”, conducted by the Department of Pathological Physiology, Danylo Halytskyi Lviv National Medical University (state registration No. 0116U004503).

The aim of the work: to study the morphological features of the colon in the dynamics of the development of experimental acute peritonitis on the background of streptozotocin-induced diabetes mellitus.

Materials and Methods. The experiment used 48 white male rats. Diabetes mellitus in experimental animals was simulated by a single intraperitoneal injection of streptozotocin (Sigma) at a rate of $60 \mathrm{mg} / \mathrm{kg}$, acute disseminated peritonitis - the introduction of $0.5 \mathrm{ml}$ of $10 \%$ filtered fecal suspension into the abdominal cavity. A morphological study of the colon in animals removed from the experiment on the first, third and seventh days of acute peritonitis on the background of concomitant diabetes mellitus was performed. Results and Discussion. Morphological examination of the colon of animals on the first day of experimental acute peritonitis in conditions of concomitant streptozotocin-induced diabetes mellitus revealed an increase in the size of the crypts due to stroma edema and lymphohistiocytic infiltration, slight perivascular edema in the subclavian edema. On the third day, thickening of the mucous membrane of the colon, a sharp increase in the depth of the crypts, uneven blood supply to the vessels in the submucosal layer with a predominance of perivascular edema were verified. On the seventh day, a decrease in the thickness of the mucous membrane due to the expansion of the crypts was visualized. Part of the epitheliocytes was in a phase of increased secretory activity, the other part was dystrophically altered, which stimulated increased lymphocytic and histiocytic infiltration.

These changes were accompanied by activation of reactive processes and hyperplasia of lymphoid follicles on the first day of peritonitis on the background of streptozotocin-induced diabetes mellitus, and as the severity of purulent inflammation - hypoplasia of the lymphoid tissue and a decrease in local reactivity(the third and seventh days of the development of acute peritoneal burning in conditions of combined pathology).
\end{abstract}

Key words: acute peritonitis; streptozotocin-induced diabetes mellitus; morphological changes of the colon.

Despite the introduction of the new methods of diagnosis and treatment, wide range of antimicrobial drugs, the mortality of patients with acute peritonitis remains high at $15.5 \%$ to $37.8 \%[1,2,3]$. The analysis of the structural distribution of concomitant pathology in patients with acute peritonitis showed the presence of a significant proportion of diabetes mellitus, which correlates from $7.9 \%$ to $16.7 \%[4,5$, 6 , 7]. Hyperglycemia increasing the growth and virulence of microorganisms, is a promoter of endothelial dysfunction and alters the course of the inflammatory process by disrupting the initial neutrophil response. Increased vascular permeability and edema as a result of hyperglycemia lead to the development of multiple organ failure [8], which is the cause of death in patients with acute generalized peritonitis (AGP) [9, 10]. One of the pathogenetic links of multiple organ failure is the enteral insufficiency syndrome, characterized by the increasing intestinal paresis, sequestration of fluid and gases, accompanied by pronounced morphological changes in the wall of the small and large intestine, which are the gateway to bacterial contamination. In the scientific literature there is no data about the morphological structure of the large in- testine in the hypoergic course of the inflammatory process of the peritoneum under the influence of hyperglycemia, which was the trigger for our study.

The aim of the work was to study the morphological features of the large intestine in the dynamics of experimental AGP against the background of streptozotocin (STZ)-induced diabetes.

Materials and Methods. The experiment was performed on 48 white male adult rats, which were divided into two groups. The main group - animals with simulated AGP against the background of STZinduced diabetes $(n=38)$. The control group - intact white rats, which were injected subcutaneously with sterile $0.9 \%$ sodium chloride solution $(\mathrm{n}=8)$.

The animals of the main group were injected with a single dose of STZ (60 mg/kg body weight) intraperitoneally dissolved in $0.1 \mathrm{M}$ citrate buffer ( $\mathrm{pH} 4.5$ ) after an overnight fast [11]. After the administration of STZ, the animals were given $1 \%$ sucrose solution to prevent hypoglycemia. Throughout the observation (14 days of diabetes modeling and during the subsequent simulation of acute peritonitis), the rats were in- 
jected subcutaneously with insulin 2 to 5 times a week, depending on blood glucose levels. Glucose studies were carried out at 9:00 with free access of experimental animals to food and water during the night period.

On the 14th day after administration of STZ, 38 animals (95\%) of the main group, in which the glucose level was more than $200 \mathrm{mg} / \mathrm{dL}$, were initiated acute peritonitis. In the experiment there was developed a model of peritonitis based on the introduction of $10 \%$ fecal suspension in the dosage of $0.5 \mathrm{ml}$ per $100 \mathrm{~g}$ of the animal's weight into the abdominal cavity of rats by puncture [12]. The fecal suspension was prepared by mixing isotonic solution and the contents of the cecum of 3 intact animals, then it was filtered twice through a double layer of gauze and injected by puncture no later than 20 min after preparation.

The euthanasia of the rats was performed under thiopental anesthesia on the 1st, 3rd and 7th days of modeling AGP accordinly to the reactive, toxic and terminal stages of the disease. As a result of death during the experiment, the number of animals in the groups at the time of euthanasia was accordingly different.

To prepare samples for histological studies, the part of the large intestine was excised with the resection area, the sample was fixed for 24 hours in $10 \%$ neutralbuffered formalin. Dehydration of the specimens was performed using ascending concentrations of ethyl alcohol and then embedded in paraffin. Sections of approximately 2-3 $\mu \mathrm{m}$ thickness were cut from tissue blocks and stained with haematoxylin and eosin, according to standard protocols. The samples thus prepared were observed with a Nikon E200 microscope with a Nikon D5000 camera with magnifications of 100.

Results and Discussion. Already on the first day of the development of AGP against the background of STZ-induced diabetes, structural changes of the wall of the large intestine were observed, which consisted in the enlargement of the epithelium of large intestine crypts, while the cell nuclei were located apically. It clearly demonstrated that the mucosa and muscle layers in the diabetic colon of the main group became much thicker than in the rats of the control group. The lumen of the crypts - slightly expanded, contained a small amount of secretion. The size of the crypts is slightly increased mainly due to stroma edema and lymphohistiocytic infiltration. The vessels of the microcirculation were poorly visualized. Uneven vascular fullness and slight perivascular edema were found in the submucosa. Hyperplasia developed in some lymphoid follicles (Fig. 1).

On the third day of acute peritonitis against the background of STZ-induced diabetes a thickening of the mucous membrane of the large intestine, the char-

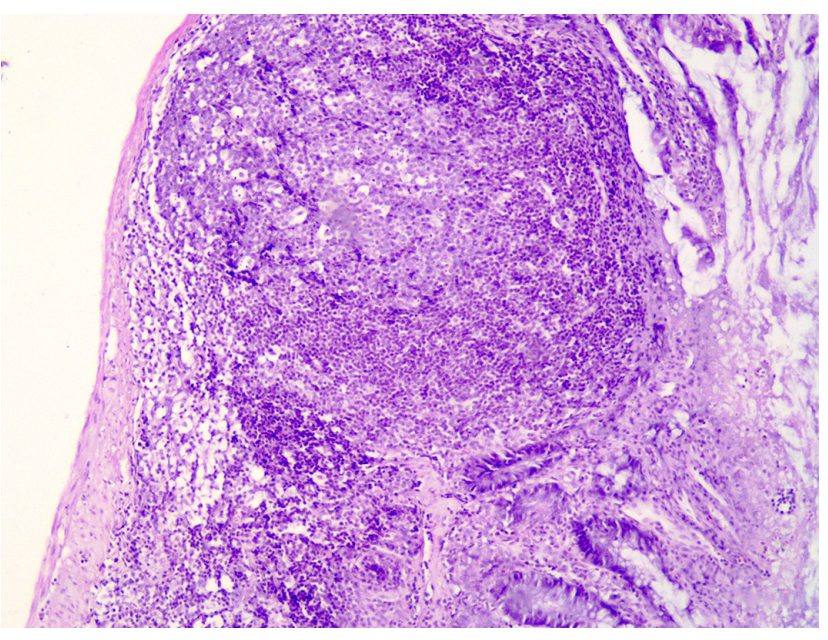

Fig. 1. Hyperplasia of lymphoid follicles. Staining with hematoxylin and eosin. $\times 200$.

acteristic apical location of the nuclei in the vast majority of epitheliocytes were revealed. The lumens of the crypts were slightly widened and contained a small amount of secretion and desquamated epithelial cells (Fig. 2). The depth of the crypts is sharply increased due to stroma edema and lymphohistiocytic infiltration. The vessels of the microcirculation were

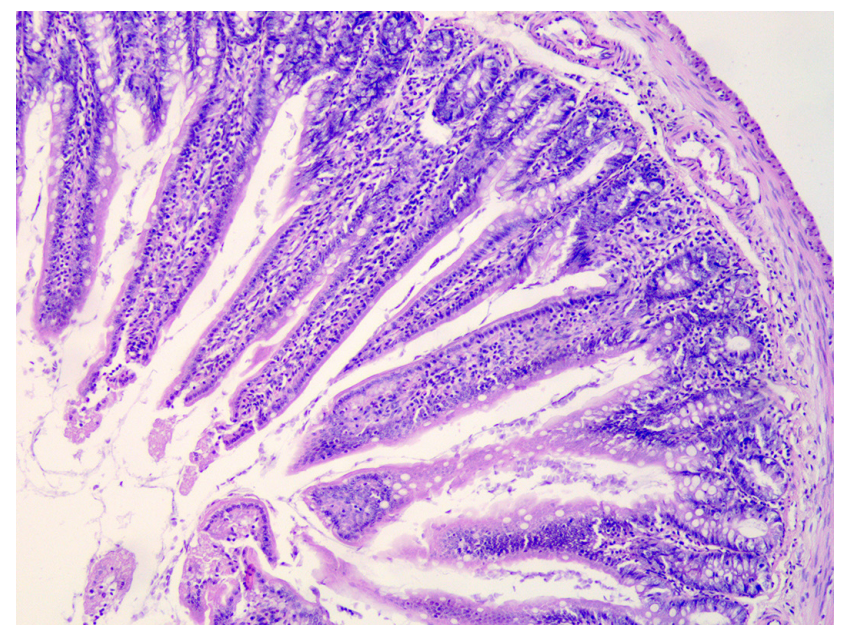

Fig. 2. The lumens of the crypts containe desquamated epithelial cells. Uneven vascular blood supply. Staining with hematoxylin and eosin. $\times 200$.

poorly visualized. Uneven vascular blood supply with predominance of perivascular edema in the submucosa was revealed as well. Lymphoid follicles were poorly visualized.

The histological examination of the structure of the wall of the large intestine on the seventh day of 
the development of combined pathology showed the growth of structural changes. The thickness of the mucous membrane was slightly reduced due to the expansion of the crypts compared to the first and third days of the study. Some epitheliocytes were in the phase of increased secretory activity, the other part was dystrophically altered, which stimulated the increase of lymphocytic and histiocytic infiltration (Fig 3). Crypt lumens remained wide in places and contained a small

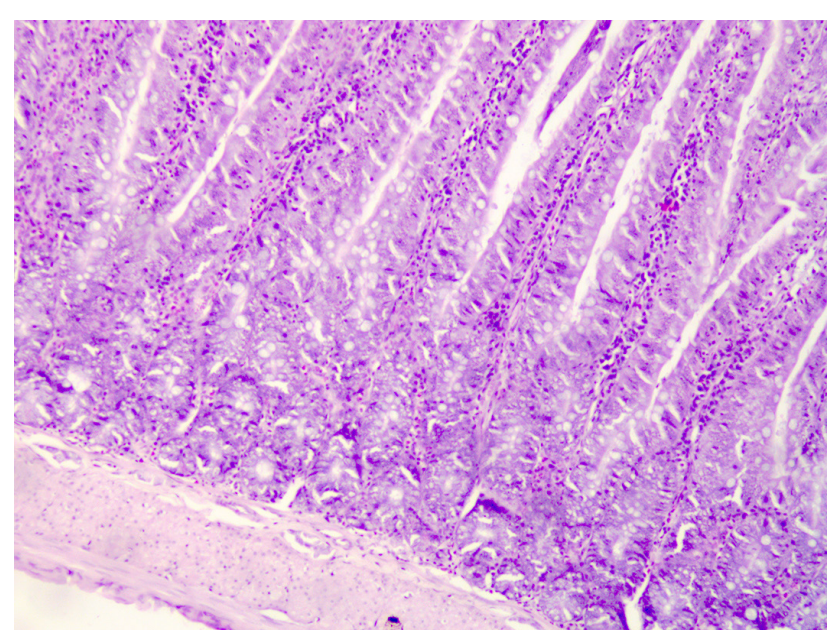

Fig. 3. The colon shows dystrophic changes of the epithelium and infiltration of inflammatory cells in the mucous membrane. Staining with hematoxylin and eosin. $\times 200$. amount of secretion. The vessels of the microcirculatory tract were poorly visualized. In the submucosa, the vessels of the microcirculatory tract were poorly visualized; the muscular membrane remained virtually unchanged. The absence of lymphatic follicles in the submucosal layer in combination with increased leukocyte infiltration indicates the depletion of the mechanisms that ensure reactivity.

The results of morphological examination of the large intestine showed that the increase in the severity of peritonitis is accompanied by the dilation of crypts, increase in their depth due to stromal edema and lymphohistiocytic infiltration, development of dystrophic changes of the mucosal epithelium, and progression of perivascular hyperplasia and the reduction of hyperplastic reactive processes on the part of the lymphatic system.

Conclusion. During the first and third days of development of experimental acute generalized peritonitis against the background of streptozotocin-induced diabetes, morphological changes of the large intestine were revealed, manifested by progressive edema, lymphohistiocytic infiltration of the stroma and perivascular inflammatory infiltrate. On the seventh day of acute peritonitis against the background of diabetes, dystrophic changes of the epithelium and the absence of lymphoid follicles in the submucosa were verified, which indicates a hypoergic course of this combined pathology.

\section{LITERATURE}

1. Etiology, treatment outcome and prognostic factors among patients with secondary peritonitis at Bugando Medical Centre, Mwanza, Tanzania / A. Mabewa, J. Seni, P. L. Chalya [et al.] // World Journal of Emergency Surgery. - 2015. - No. 10. - P. 47. 2. Afuwape O. O. Base excess and $\mathrm{pH}$ as predictors of outcomes in secondary peritonitis in a resource limited setting - A prospective study / O. O. Afuwape, O. Ayandipo, S. Aroso // Journal of Clinical Sciences. - 2020. - Vol. 17 (4). - P. 145-149.

3. The delta neutrophil index is a prognostic factor for postoperative mortality in patients with sepsis caused by peritonitis / J. W. Kim, J. H. Park, D. J. Kim [et al.] // PLOS One. - 2017. Vol. 12 (8). - P. e0182325.

4. Comparison of peritoneal lavage with normal saline and normal saline plus antibiotic in acute peritonitis / M. Raeeszadeh, S. M. J. Hosseini, M. T. Khanmohammadi [et al.] // Trauma Monthly. - 2017. - Vol. 22 (5). - P. e58188.

5. Multicenter study evaluating the role of enterococci in secondary bacterial peritonitis / E. Cercenado, L. Torroba, R. Canto'n [et al.] // Journal of Clinical Microbiology. - 2010. - Vol. 48 (2). - P. 456-459.

6. Patients with faecal peritonitis admitted to European intensive care units: an epidemiological survey of the GenOSept cohort / A. Tridente, G. M. Clarke, A. Walden [et al.] // Intensive Care Medi-

cine. - 2014. - Vol. 40 (2). - 202-210.

7. Ross J. T. Secondary peritonitis: principles of diagnosis and intervention / J. T. Ross, M. A. Matthay, H. W. Harris // British Medical Journal. - 2018. - 361. - P. k1407.

8. Steinberg B.E. Do viral infections mimic bacterial sepsis? The role of microvascular permeability: A review of mechanisms and methods / B. E. Steinbert, N. M. Goldenberg, W. L. Lee // Antiviral Research. - 2012. - Vol. 93 (1). - P. 2-15.

9. Analysis of organ failure and mortality in sepsis due to secondary peritonitis / J. Hernández-Palazón, D. Fuentes-García, S. Burguillos-López [et al.] // Medicina Intensiva. - 2013. Vol. 37 (7). - P. 461-467.

10. Factores relacionados con la falla multiorgánica en pacientes con peritonitis / S. R. Elías, L. J. O. Fernández, U. T. Choo [et al.] // Revista Cubana de Cirugía. - 2019. - Vol. 58(4). - P. e860.

11. Ramos-Lobo A. M. Streptozotocin-induced diabetes disrupts the body temperature daily rhythm in rats / A. M Ramos-Lobo, D. C. Buonfiglio, J. Cipolla-Neto // Diabetology \& Metabolic Syndrome. - 2015. - No. 7. - P. 39.

12. Экспериментальная модель распространенного калового перитонита / В. А. Лазаренко, В. А. Липатов, Ю. Ю. Блинков, Д. В. Скориков // Курский научно-практический вестник “Человек и его здоровье”. - 2008. - № 4. - С. 128-132. 


\section{REFERENCES}

1. Mabewa, A., Seni, J., Chalya, P.L., Mshana, S.E., \& Gilyoma, J.M. (2015). Etiology, treatment outcome and prognostic factors among patients with secondary peritonitis at Bugando Medical Centre, Mwanza, Tanzania. World Journal of Emergency Surgery, 10, 47. DOI: 10.1186/s13017-015-0042-5

2. Afuwape, O.O., Ayandipo, O., \& Aroso, S. (2020). Base excess and $\mathrm{pH}$ as predictors of outcomes in secondary peritonitis in a resource limited setting - A prospective study. Journal of Clinical Sciences, 17 (4), 145-149. DOI: 10.4103/jcls.jcls_18_20

3. Kim, J.W., Park, J.H., Kim, D.J., Choi, W.H., Cheong, J.C., \& Kim, J.Y. (2017). The delta neutrophil indexis a prognostic factor for postoperative mortality in patients with sepsis caused by peritonitis. PLOS One, 12 (8), e0182325. DOI: 10.1371/journal. pone. 0182325

4. Raeeszadeh, M., Hosseini, S.M.J., Khanmohammadi, M.T., Manoochehry, S., \& Rasouli, H.R. (2017). Comparison of peritoneal lavage with normal saline and normal saline plus antibiotic in acute peritonitis. Trauma Monthly, 22 (5), e58188. DOI: 10.5812/ traumamon.58188

5. Cercenado, E., Torroba, L., Cantón, R., Martínez-Martínez, L., Chaves, F., ... \& Bouza, E. (2010). Multicenter study evaluating the role of enterococci in secondary bacterial peritonitis. Journal of Clinical Microbiology, 48 (2), 456-459. DOI: 10.1128/ JCM.01782-09

6. Tridente, A., Clarke, G.M., Walden, A., McKechnie, S., Hutton, P., ... \& GenOSept Investigators. (2014) Patients with faecal peritonitis admitted to European intensive care units: an epidemiological survey of the GenOSept cohort. Intensive Care Medicine, 40 (2), 202-210. DOI: 10.1007/s00134-013-3158-7

Електронна адреса для листування: danaverveha@gmail.com
7. Ross, J.T., Matthay, M.A., \& Harris, H.W. (2018). Secondary peritonitis: principles of diagnosis and intervention. British Medical Journal, 361, k1407. DOI:10.1136/bmj.k1407

8. Steinberg, B.E., Goldenberg, N.M., \& Lee, W.L. Do viral infections mimic bacterial sepsis? (2012). The role of microvascular permeability: A review of mechanisms and methods. Antiviral Research, 93 (1), 2-15. DOI: 10.1016/j.antiviral.2011.10.019. 9. Hernández-Palazón, J., Fuentes-García, D., Burguillos-López, S., Domenech-Asensi, P., Sansano-Sánchez, T.V., \& Acosta-Villegas, F. (2013). Analysis of organ failure and mortality in sepsis due to secondary peritonitis. Medicina Intensiva, 37 (7), 461-467. DOI:10.1016/j.medin.2012.07.010

10. Elías, S.R., Fernández, L.J.O., Choo, U.T., Bordelois, A.M.S., \& Lecourtois, M.L. (2019). Factores relacionados con la falla multiorgánica en pacientes con peritonitis. Revista Cubana de Cirugía, 58 (4), e860. Retrieved from: https://www.medigraphic. com/pdfs/cubcir/rcc-2019/rcc194e.pdf

11. Ramos-Lobo, A.M., Buonfiglio, D.C., \& Cipolla-Neto, J. (2015). Streptozotocin-induced diabetes disrupts the body temperature daily rhythm in rats. Diabetology \& Metabolic Syndrome, 7, 39. DOI 10.1186/s13098-015-0035-2

12. Lazarenko, V.A., Lipatov, V.A., Blinkov, Yu.Yu., \& Skorikov D.V. (2008). Eksperimentalnaya model rasprostranennogo kalovogo peritonita [Experimental model of diffuse fecal peritonitis]. Kurskiy nauchno-prakticheskiy vestnik "Chelovek i ego zdorovye" - Kursk Scientific and Practical Bulletin "Man and His Health”, 4, 128-132. Retrieved from: https://cyberleninka.ru/ article/n/eksperimentalnaya-model-rasprostranennogo-kalovogoperitonita [in Russian].

Отримано 22.03.2021

\section{5. М. ВЕРВЕГА}

Львівський національний медичний університет імені Данила Галицького

\section{МОРФОЛОГІЧН ОСОБЛИВОСТІ ТОВСТОӤ КИІКИ ПРИ ЕКСПЕРИМЕНТАЛЬНОМУ ГОСТРОМУ ПОІІИРЕНОМУ ПЕРИТОНІТІ НА ТЛІ СТРЕПТОЗОТОЦИНІНДУКОВАНОГО ЦУКРОВОГО ДІАБЕТУ}

\footnotetext{
Мета роботи: дослідити морфологічні особливості товстої кишки в динаміці розвитку експериментального гострого поширеного перитоніту на тлі стрептозотоциніндукованого цукрового діабету.

Матеріали і методи. В експерименті використано 48 білих щурів-самців. Цукровий діабет у дослідних тварин моделювали шляхом одноразового інтраперитонеального введення стрептозотоцину (Sigma) з розрахунку 60 мг/кг, гострий поширений перитоніт - введенням 0,5 мл 10 \% профільтрованої калової суспензії в черевну порожнину. Проводили морфологічне дослідження товстої кишки у тварин, виведених із експерименту на першу, третю та сьому доби розвитку гострого запалення очеревини на фоні супутнього цукрового діабету.

Результати досліджень та їх обговорення. При морфологічному дослідженні товстої кишки тварин на першу добу експериментального гострого поширеного перитоніту за умов супутнього стрептозотоциніндукованого цукрового діабету виявлено збільшення величини крипт за рахунок набряку строми й лімфогістіоцитарної інфільтрації, незначний периваскулярний набряк у підслизовому шарі. На третю добу верифіковано потовщення слизової оболонки товстої кишки, різке збільшення глибини крипт, нерівномірне кровонаповнення судин у підслизовому шарі із переважанням периваскулярного набряку. На сьому добу візуалізували зменшення товщини слизової оболонки за рахунок розширення крипт. Частина епітеліоцитів перебувала у фазі підвищеної секреторної активності, інша частина була дистрофічно змінена, що стимулювало посилення лімфо- та гістіоцитарної інфільтрації.

Дані зміни супроводжувались активацією реактивних процесів та гіперплазією лімфоїдних фолікулів вже на першу добу розвитку перитоніту на фоні стрептозотоциніндукованого цукрового діабету, а по мірі наростання важкості запалення - гіпоплазією зі сторони лімфоїдної тканини та зниженням місцевої реактивності (третя та сьома доби розвитку гострого запалення очеревини в умовах поєднаної патології).
}

Ключові слова: гострий поширений перитоніт; стрептозотоциніндукований цукровий діабет; морфологічні зміни товстої кишки 


\section{МОРФОЛОГИЧЕСКИЕ ОСОБЕННОСТИ ТОЛСТОЙ КИШКИ ПРИ ЭКСПЕРИМЕНТАЛЬНОМ ОСТРОМ РАСПРОСТРАНЕННОМ ПЕРИТОНИТЕ НА ФОНЕ СТРЕПТОЗОТОЦИНИНДУЦИРОВАННОГО САХАРНОГО ДИАБЕТА}

Цель работы: изучить морфологические особенности толстой кишки в динамике развития экспериментального острого распространенного перитонита на фоне стрептозотоцининдуцированного сахарного диабета.

Материалы и методы. В эксперименте использовано 48 белых самцов крыс. Сахарный диабет в экспериментальных животных моделировали путем однократной интраперитонеальной инъекции стрептозотоцина (Sigma) в дозе 60 мг/кг, острый распространенный перитонит - введением 0,5 мл 10 \% профильтрованной каловой суспензии в брюшную полость. Проводили морфологическое исследование толстой кишки у животных, выведенных из эксперимента на первые, третьи и седьмые сутки развития острого распространенного перитонита при сопутствующем сахарном диабете.

Результаты исследований и их обсуждение. При морфологическом исследовании толстой кишки животных на первые сутки экспериментального острого распространенного перитонита на фоне сопутствующего стрептозотоцининдуцированого сахарного диабета были выявлены увеличение величины крипт за счет отека стромы и лимфогистиоцитарной инфильтрации, незначительный периваскулярный отек в подслизистом слое. На третьи сутки верифицировано утолщение слизистой оболочки толстой кишки, резкое увеличение глубины крипт, неравномерное кровенаполнение сосудов в подслизистом слое с преобладанием периваскулярного отека. На седьмые сутки толщина слизистой оболочки была несколько уменьшена за счет расширения крипт. Часть эпителиоцитов находилась в фазе повышенной секреторной активности, другая часть была дистрофически изменена, что стимулировало усиление лимфо- и гистиоцитарной инфильтрации.

Данные изменения сопровождались активацией реактивных процессов и гиперплазией лимфоидных фолликулов на первые сутки развития перитонита на фоне стрептозотоцининдуцированого сахарного диабета, а по мере наростания тяжести воспаления - гипоплазией со стороны лимфоидной ткани и снижением местной реактивности (третьи и седьмые сутки экспериментального моделирования острого воспаления брюшины в условиях сочетанной патологии).

Ключевые слова: острый распространенный перитонит; стрептозотоцининдуцированный сахарный диабет; морфологические изменения толстой кишки. 